\title{
Adaptability of Cattle-Raising to Multiple Stressors in the Dry Tropics of Chiapas, Mexico
}

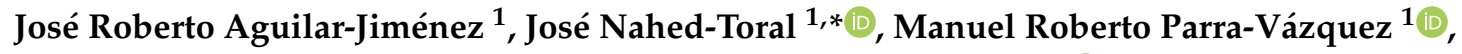 \\ Francisco Guevara-Hernández ${ }^{2}$ and Lucio Alberto Pat-Fernández ${ }^{1}$ (D) \\ 1 El Colegio de La Frontera Sur. Carretera Panamericana y Periférico Sur s/n. Barrio de María Auxiliadora, \\ pc. 29290 San Cristóbal de Las Casas, Mexico; jraguilar@ecosur.edu.mx (J.R.A.-J.); \\ mparra@ecosur.mx (M.R.P.-V.); lpat@ecosur.mx (L.A.P.-F.) \\ 2 Facultad de Ciencias Agronómicas, Universidad Autónoma de Chiapas, México, \\ Carretera Ocozocoautla-Villaflores km. 84.5, pc. 30470 Villaflores, Mexico; fragueher@prodigy.net.mx \\ * Correspondence: jnahed@ecosur.mx; Tel.: +52-9676-749000-1416
}

Received: 5 January 2019; Accepted: 28 March 2019; Published: 2 April 2019

\begin{abstract}
Using the sustainable livelihoods analytical framework, the adaptability of cattle-raising to multiple stressors (e.g., climate change and market conditions) in the dry tropics of Chiapas, Mexico, was evaluated. Three case studies located in the Frailesca region of Chiapas were analyzed: (I) peasant cattle raising in a rural village in the Frailesca Valley; (II) peasant cattle raising in a rural village in a natural protected area in the Frailesca Highlands; and (III) holistic cattle raising by farmers with private land ownership in the Frailesca Valley. Three livelihood strategies were identified: a cattle raising-crop cultivation strategy with high use of purchased inputs (case 1); (II) a diversified strategy including extensive livestock raising (case 2); and (III) a strategy specialized in holistic cattle raising (case III). Adaptability was evaluated using an index on a scale of 1 to 100; average values were: case $\mathrm{I}=20.9 \pm 1.4$; case II $=32.1 \pm 1.8$; and case III $=63.6 \pm 3.5$. In order to increase farms' adaptability and reduce the vulnerability of cattle-raising families, there is a need to modify public policy to take into account the conditions of the most vulnerable farmers (cases I and II). Given the economic, environmental, and social context of Mexico's dry tropics, establishing ecological or organic cattle raising and silvopastoral systems may reduce farm families' vulnerability and increase the level of adaptability of their farms to multiple stressors.
\end{abstract}

Keywords: adaptive capacity; multiple stressors; sustainable livelihoods; silvopastoral systems; organic cattle raising

\section{Introduction}

Cattle-raising is significant to the ways of life of many peasant families in Latin America and the Caribbean, and currently provides $46 \%$ of agricultural GDP in these regions, which provide over a fourth of the world's beef [1]. However, cattle-raising has been shown to result in environmental impacts, including deforestation, soil and water contamination, and greenhouse gas emissions [2].

Despite the fact that $63.5 \%$ of Mexico's cattle are raised in tropical areas, productivity is low; while $37 \%$ of Mexico's surface area consists of tropical areas, they provide only $17 \%$ of the nation's milk produced [3] and approximately $28 \%$ of its meat [4]. Therefore, there is a need to increase productivity of tropical cattle-raising in a sustainable manner in order to reduce environmental impacts and mitigate rural poverty in a context in which structural adjustments such as free trade and elimination of subsidies have worsened farmers' economic and social situation-particularly the poorest farmers.

Farmers commonly face problems such as volatility of the prices of their products, increase in input prices, and dependence on intermediaries as well as on large national and transnational 
businesses that control the purchasing of products and input sales. Furthermore, they also confront the effects of climate change, such as temperature increases, changes in distribution and frequency of precipitation, and an increase in hurricanes [5]. Climate change is expected to gradually reduce productivity of tropical agroecosystems [6]; changes in precipitation and temperature may affect tropical livestock raising due to increased droughts and floods that may reduce water availability, quantity and quality of fodder, and biodiversity while increasing crop pests and diseases in both humans and animals [7]. Such environmental, economic, and social stress factors that jointly affect farmers over time are known as multiple stressors [8,9].

From a sustainable livelihoods (SL) approach, reducing vulnerability of farm families and taking advantage of new opportunities resulting from multiple stressors involves changes in livelihood strategies or adaptation. Most disciplines conceive vulnerability to be the extent to which a system, subsystem, or component of a system is likely to undergo damage due to exposure to a threat [10]. With respect to climate change, vulnerability results from exposure to a threat (stress factor) or threats (multiple stressors) and varies according to the system's sensitivity and its ability to respond to these stressors (adaptability or adaptive capacity) [11]. Adaptability, or adaptive capacity, is defined as the ability of a system to modify itself to avoid negative effects of a variety of stressors or to respond to disturbances [12]. Adaptive capacity also involves a system's ability to take advantage of opportunities that arise in the context of stress factors [6].

The concept of adaptability is commonly used to evaluate responses of farmers to climate change. Few studies have evaluated the adaptive capacity of cattle farms in the face of multiple stressors in a multidimensional manner [8]. The sustainable livelihoods analytical framework allows for carrying out such a multidimensional analysis of farm systems.

Within the sustainable livelihoods framework, evaluations of adaptability provide information regarding availability of capitals (natural, physical, financial, social, and human) which may contribute to natural resource management, as well as factors which limit farmers' abilities to access these capitals in order to adapt to change. Cattle farms' levels of vulnerability and adaptability will depend on a variety of factors, including farmers' organizational capacity; their access to resources such as technology, information, and financial services; the sociopolitical environment [11,13]; and knowledge construction and transmission [14].

The sustainable livelihoods approach allows for identifying causes of vulnerability of groups of people or systems in order to suggest measures for reducing this vulnerability and improving the system's adaptability.

This study analyzes farm families' livelihood strategies as well as those factors that determine the adaptability of cattle-raising systems to multiple stressors in three cases in the dry tropics of the Mexican state of Chiapas, and proposes ways of increasing local adaptive capacity as well as improving the effectiveness of public policy.

\section{Case Studies}

In the early XX century, Mexico's agrarian policy fomented land settlement. This led to the foundation of many ejidos [15] — rural communities in which each family has private ownership of land for residential and agricultural use and the community as a whole owns land used for schools, churches, and other public buildings; forest reserves; and in some cases collective agricultural land. Two of the three cases of the present study are ejidos: Calzada Larga, located in the Frailesca Valley, and Los Angeles located in the Frailesca Highlands, both in the dry tropics of the Mexican state of Chiapas (Figure 1). The Frailesca region, which lies between the Sierra Madre and the Central Depression of Chiapas, owes its name to the Spanish monks (frailes) who inhabited the region in the early part of the Colonial period. Currently the majority of the population is mestiza. Principle agricultural crops include staple foods (maize and beans) and coffee (at higher elevations); cattle raising and industrial chicken production are also principle economic activities. In the eastern part of the region, fishing and coffee production predominate. The current study was carried out in the western part of the Frailesca 
region, and addresses cattle raising in the Frailesca Valley and the Highlands (Figure 1)—two regions with very different environmental characteristics and histories.

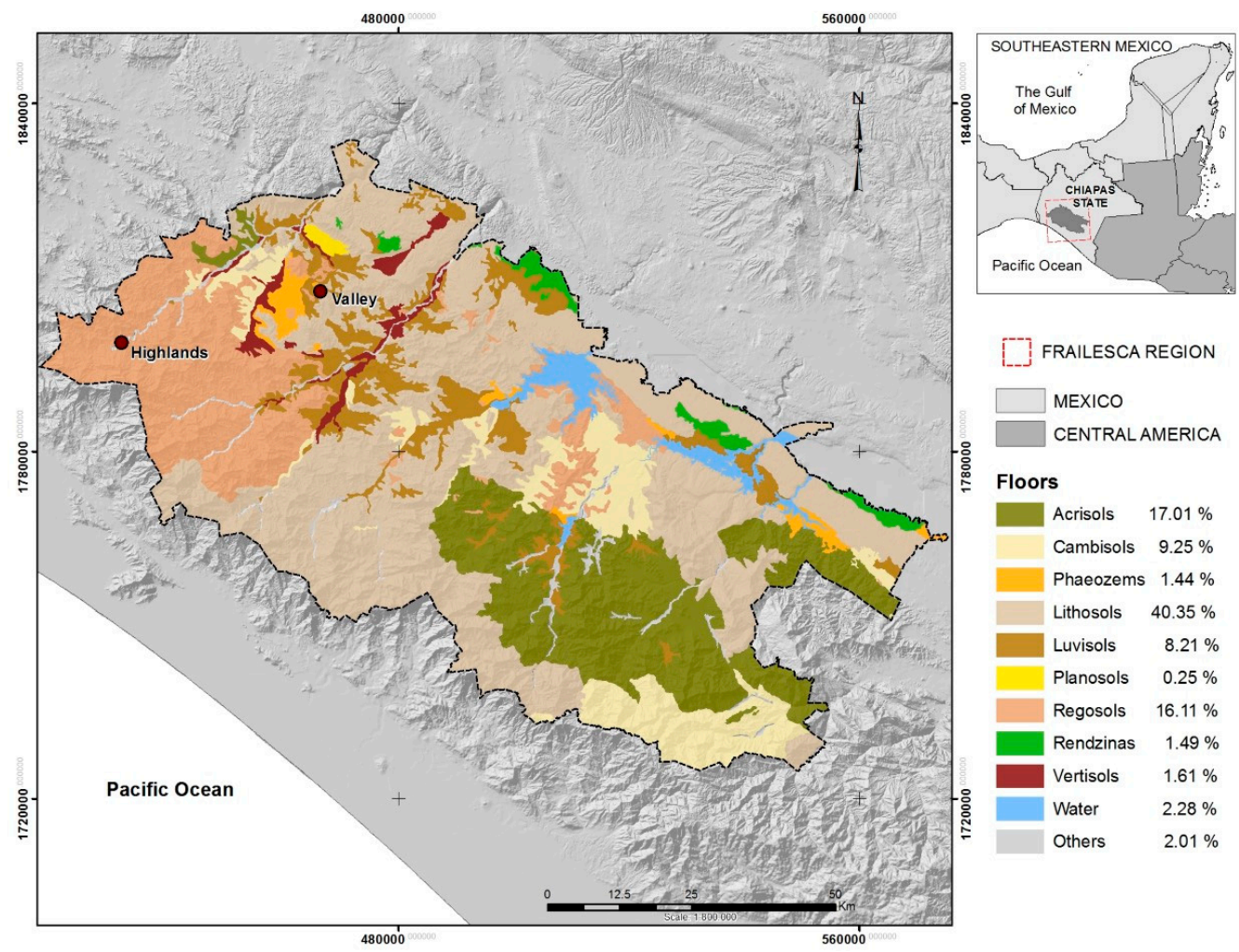

Figure 1. Soil map-based on [16] —and location of the Frailesca region in the dry tropics of the southeastern Mexican state of Chiapas.

According to the national statistical institute INEGI [16], the study region includes nine soil types (Figure 1). The Highlands include several soil associations, with a predominance of Regosols, which cover $16.11 \%$ of the Frailesca region or a surface area of 128,863 ha. Regosols generally are located on slopes, erosion is common, and these are not very consolidated soils. As Regosols have little capacity for water retention, they are more appropriate for forestry rather than agriculture. However, in the Frailesca region, land with Regosols is commonly used for grazing and staple foods.

The Frailesca Valley includes several soil associations. The most common soil type is Lithosols, which covers $40.35 \%$ of the study region, or a surface area of 322,846 ha. Lithosols, which are less than $10 \mathrm{~cm}$ deep, do not allow for root growth and, therefore, are not very fit for crop agriculture. In the area of the Frailesca Valley where the present study was carried out (Figure 1), Lithosols form a variety of associations with Luvisols, Phaeozems, and Vertisols (all of which are deeper than Lithosols), each covering a small surface area. Soils in the Frailesca Valley are commonly used for growing maize and other grains, as well as for grazing. The Frailesca Valley's high soil fertility favored an increase in agriculture in the 1960s, and the Frailesca region thus became known as southern Mexico's "granary"; typical maize harvests on the flat alluvial valley floors yielded 5-8 metric tons per hectare [17].

Figure 1 shows that the association of Acrisols and Cambisols is also common in the Frailesca region, although in areas far from the Valley rather than where the present study was carried out.

In the early XX century, aside from ejidos, small private cattle ranches were also established, such as those of the Frailesca Valley. The level geography of the Valley favored implementation of Green Revolution agriculture based on mechanization, high levels of agrochemicals, and improved seeds, and this model still prevails today.

Calzada Larga farmers practice an extensive grazing system. These farmers use agrochemicals for fodder production and, given the scarcity of grass during the drought (December to May), they also 
purchase feed, including chicken manure (produced from the region's industrial chicken farms), hay, and maize.

Despite dominance of the Green Revolution model in the Frailesca Valley, in 1994 seven farmers with private landholdings - who conform the third case-formed an informal organization to train themselves in intensive grazing practices, and thereby transitioned from conventional to holistic cattle-raising [18] with the help of training in Mexico and abroad at their own expense as well as government funding. Holistic cattle-raising is based on sustainable principles and techniques [19]. For example, all the holistic farms evaluated include a reserve to conserve flora and fauna, and these farmers raise a diversity of fodder species, rotate pastures according to a planned rotational grazing scheme, and make little use of agrochemicals.

Demographic growth in the Frailesca Valley led to settlement of the Frailesca Highlands. The Los Angeles ejido, founded in 1960, is one of the first such settlements. In the early years, farmers principally grew maize on sloped land using slash and burn techniques. Later, with the increase in maize production in the Frailesca Valley (1970-1994), the Green Revolution also permeated the highlands, leading to deforestation of large areas to cultivate maize with agrochemicals. The abrupt fall in maize prices as a consequence of NAFTA and an increase in remittances by migrants-principally in the United States—contributed to development of cattle-raising in the Frailesca Highlands. In 1995, The Sepultura Biosphere Reserve (REBISE according to its Spanish initials) was created in the highlands, resulting in regulations regarding natural resource use which have often been prohibitive to farmers. As in the rest of the Sierra Madre of Chiapas, the Frailesca part of the Sierra included in the present study is significant as it is located in the high watershed of the Tablon River, which is the principle source of fresh water, used for human consumption as well as for agriculture in rural communities in the Highlands, as well as downstream in the Valley.

\subsection{Technical-Economic Characteristics of Cattle Farms}

Table 1 presents some technical-economic indicators used to characterize the three cattle-raising systems. Cattle raising in the Los Angeles ejido has involved extensive grazing. The dominant agricultural landscape in this ejido consists of pastures and small plots for growing staple foods (principally maize and beans). In general, Los Angeles farmers use fewer external inputs for cattle raising than both groups in the valley. During droughts, cattle directly feed on maize harvest residues in the field.

Table 1. Technical-economic indicators (average value \pm standard error) of cattle farms in three case studies in the dry tropics of Chiapas, Mexico.

\begin{tabular}{lccc}
\hline & \multicolumn{3}{c}{ Frailesca Region } \\
\cline { 2 - 4 } & Highlands & \multicolumn{2}{c}{ Valley } \\
\hline Indicators & Los Angeles & Calzada Larga & Holistic Farmer \\
\hline Total land surface, ha & $58.3( \pm 8.19)$ & $16.3( \pm 1.7)$ & $112.7( \pm 17.4)$ \\
Grazing surface, ha & $45.9( \pm 6.5)$ & $13.9( \pm 12.5)$ & $92.1( \pm 1.3)$ \\
Total animal units * AU & $28.9( \pm 3.2)$ & $31.2( \pm 3.1)$ & $180.4( \pm 28.1)$ \\
Stocking rate, AU/ha & $0.8( \pm 0.06)$ & $2.6( \pm 0.2)$ & $2.1( \pm 0.3)$ \\
Cattle production system, \% & & & \\
$\quad$ Sell calf after weaning & 57.9 & 16.7 & 6.5 \\
$\quad$ Dual purpose & 42.1 & 83.3 & 93.5 \\
Calf produced/ha, num. & $0.3( \pm 0.02)$ & $1.0( \pm 0.1)$ & $0.7( \pm 0.08)$ \\
Milk produced/cow per year, 1 & $180.0( \pm 43.2)$ & $1844.8( \pm 137.9)$ & $2059.1( \pm 129.1)$ \\
Milk produced/ha per year, 1 & $72.7( \pm 15.9)$ & $2970.6( \pm 308.3)$ & $2117.1( \pm 263.0)$ \\
Net margin/cow per year, MX \$ & $1735.6( \pm 278.7)$ & $3270.8( \pm 269.4)$ & $7649.1( \pm 1881.0)$ \\
Net margin/ha per year, MX \$ & $716.7( \pm 69.3)$ & $5340.8( \pm 556.1)$ & $8559.1( \pm 2650.0)$ \\
\hline Ant
\end{tabular}

* Animal units (AU): cow-calf = $1.25 \mathrm{AU}$; pregnant cow = $1 \mathrm{AU}$; non-pregnant cow = $0.9 \mathrm{AU}$; bull = $1.25 \mathrm{AU}$; steer $=0.9 \mathrm{AU}$; heifer $=0.9 \mathrm{AU}$; weaned calf $=0.5 \mathrm{AU}$; sheep $=0.2 \mathrm{AU}$; and horse $=1.0 \mathrm{AU}$. Source: developed from original field data. 
Cattle farms of the Frailesca Valley are principally dual-purpose cattle-raising systems (Table 1) in which until calves reach their natural weaning age, they are typically allowed to nurse briefly in order to stimulate the mother's milk flow [20].

Calzada Larga farmers have the smallest total surface areas as well as the smallest pastures, and animal load in their pastures is higher than that of the holistic farms. Calzada Larga farms' annual milk production per cow is slightly lower than that of the holistic farms, although the number of calves born and annual milk yield per hectare are higher on the Calzada Larga farms than on the holistic ranches. However, this does not translate into net profit margin, which on average is higher on the holistic ranches than on Calzada Larga farms. Despite their greater yield per hectare, the lower net margin of Calzada Larga farms is probably due to the fact that farmers use high levels of external inputs to sustain production, which elevates production cost, whereas production techniques implemented on the holistic farms reduce production costs, allowing for higher net margins.

Most Los Angeles farmers do not sell milk, but rather produce calves to be sold after weaning. Those who do produce milk do so for a maximum of six months of the year, stopping production during the dry season. Average surface area of Los Angeles farms is higher than that of Calzada Larga farms, but lower than that of the holistic farms. As Los Angeles farmers practice extensive grazing on sloped pastures with fairly unproductive grasses, their pasture stocking rate is low (Table 1). However, these farmers use low levels of external inputs, and therefore their production costs are low. Nevertheless, given their low production levels, they have the lowest net margins of the three cases.

\subsection{Regional Vulnerability and Multiple Stressors}

The principal stress factors identified on all three farms were drought and market conditions (low product prices, increase in input prices, and involvement of intermediaries).

\subsubsection{Climate Change and Drought}

Within Mexico, Chiapas is one of the states with the highest levels of physical and social vulnerability to natural disasters, including extreme climatic events such as hurricanes, heavy rains, and floods, which have increased in frequency and intensity in recent decades [21], as well as volcanic eruptions, earthquakes, and landslides. For example, in 2005 Hurricane Stan damaged 208,064 hectares of crops and grasslands [22]. Such phenomena usually have dire consequences for farmers in mountainous environments, such as those of the Los Angeles ejido. Such landscapes typically contain Lithosols and Rendzinas, which are highly susceptible to erosion, especially in deforested areas.

The phenomena "el niño" and "la niña" are opposite phases of what is known as the El Niño-Southern Oscillation (ENSO) cycle and affect intensity and frequency of rain. In Chiapas, "el niño" inhibits rain, causing prolonged droughts, whereas "la niña" generally provokes heavy rain [23].

Over the past 100 years, average annual temperature in the Frailesca region has increased $1.4^{\circ} \mathrm{C}$, and total annual precipitation has decreased by $200 \mathrm{~mm}$ [22]. Farmers state that droughts have become increasingly severe in the Frailesca region. Drought generally leads to an increase in overgrazing, and in turn soil compaction and degradation [24], and propitiates malnutrition and even the death of cattle. Dry tropical cattle raising systems which principally depend on grazing-such as those of all three case studies—are particularly vulnerable to drought [25].

\subsubsection{Market Conditions}

Farmers of all three case studies generally feel they receive unfair prices for their products. This is largely due to the fact that the globalization of agribusiness has led large corporations to gain control over all stages of the food production process, from cultivation to marketing. This has principally impacted small-scale farmers who have little land, infrastructure, or financial resources. According to the United States Department of Agriculture (USDA) [26], seven businesses (Sukarne, Grupo Arias, Frigorifica Contreras, Procarne (Don Fileto), Carnes ViBa, Carnes el Alba, Consorcio Dipsen, 
and Frigorífico Tabasco) control all processes from fattening animals to marketing for $75 \%$ of beef from cattle sacrificed in Mexican government-licensed slaughterhouses. Meanwhile, over 60\% of Mexico's milk production is controlled by seven businesses (Grupo Lala, Alpura, Nestle, Sigma Foods, Dannon, Derivados de la Leche La Esmeralda, and Yakult Honsha) [26].

Corporate control of the market for cattle products results in farmers receiving a small share of sale prices, which they perceive to be "unfair", whereas consumers pay much higher prices and the majority of profits end up in the hands of corporations. The North American Free Trade Agreement (NAFTA) also harmed small-scale cattle raisers, as it led to competition by imported products, resulting in price decreases for Mexican farmers [27]. Farmers state that in the Frailesca region, intermediaries control prices and marketing of products-principally for live cattle and milk.

\section{Materials and Methods}

\subsection{Location and Characteristics of the Study Area}

The present study was carried out in 2011 in the municipality of Villaflores, in the Frailesca region of the Mexican state of Chiapas (Figure 1). This region includes two geographic areas with contrasting climates, forms of agriculture, and histories: the highlands and the valley.

The study area is located between $15^{\circ} 35^{\prime}$ and $16^{\circ} 33^{\prime} \mathrm{N}$ latitude and $92^{\circ} 12^{\prime}$ and $93^{\circ} 45^{\prime} \mathrm{W}$ longitude. In the valley, average altitude is 550 masl, climate is warm sub-humid with summer rain [28], native vegetation is deciduous tropical forest, and soil is principally alluvial loam over calcareous bedrock [29]. In the highlands, altitude ranges from 600-2000 masl and climate is semi-warm humid with abundant summer rain [28]. Agriculture in the highlands is principally carried out on steep slopes $\left(>30^{\circ}\right)$ with coarse sandy soil (mainly Regosol) [30].

\subsection{Methodology}

\subsubsection{Sustainable Livelihoods Analytical Framework}

The sustainable livelihoods (SL) analytical framework [31] was used to characterize and compare farmers' livelihoods and analyze those factors which determine the level of adaptability to multiple stressors of the above-mentioned cases of cattle raising.

The SL analytical framework is often presented in a schematic form (Figure 2). According to the Department for International Development [31], the SL framework helps to identify the interrelationships among factors affecting the livelihoods of individuals, families, and other groups. This framework addresses different types of capitals (natural, social, physical, financial, and human), vulnerability, structures, institutions and processes, livelihood strategies, and outcomes (Figure 2).

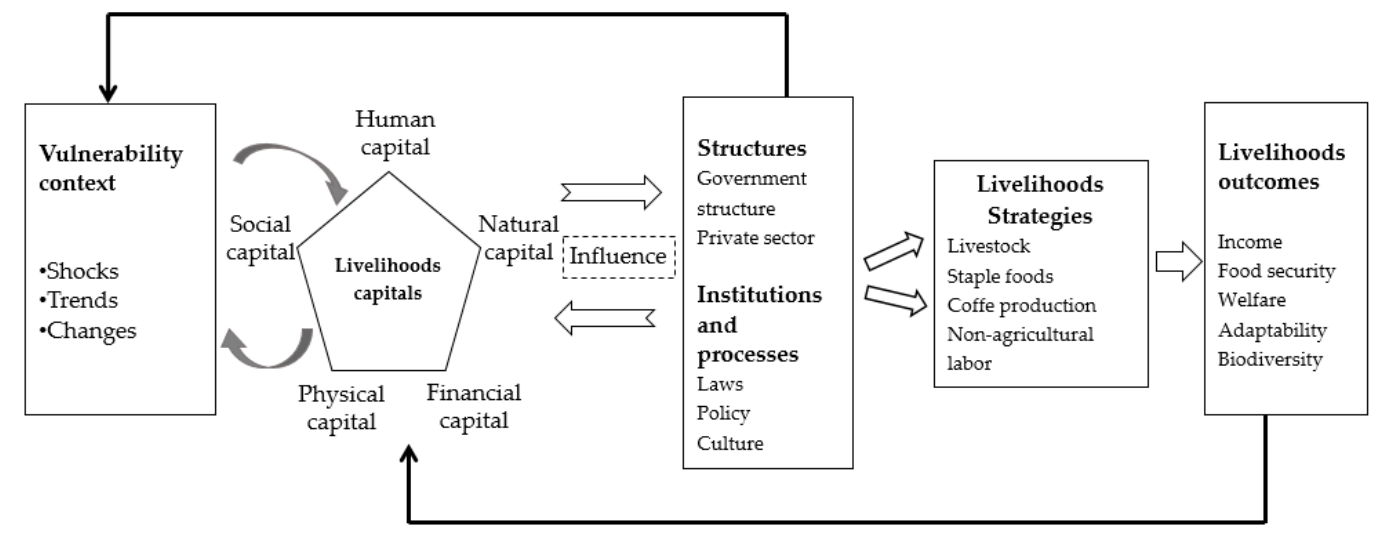

Figure 2. Sustainable livelihoods analytical framework. Adapted from the Department for International Development [31]. 
In general, the framework evaluates the ways in which people combine and use their capitals to develop their livelihood strategies, and how they are able to increase their assets by interacting with other social actors while confronting-or taking advantage of-government regulations as well as guidelines of other institutions with which they interact [32].

According to Adato and Meizen-Dick [33], farmers have five types of capital: (I) natural (land, water, forests, air quality, biodiversity); (II) social (networks, reciprocity, membership in organizations); (III) physical (technology, buildings, transportation and other infrastructure); (IV) financial (savings, loans, government support, remittances); and (V) human (education, skills, knowledge, health).

Livelihood strategies are understood to consist of the combination of families' activities and decisions aimed at attaining their objectives. These strategies may positively and/or negatively impact family welfare, adaptability, biodiversity, and/or natural resources (livelihood outcomes). A livelihood is sustainable if the family is able to cope with and recover from stress and shocks, maintain or enhance their capabilities and assets, and provide sustainable livelihood opportunities for the next generation, and if that livelihood contributes net social and environmental benefits on a local and global level in the short and long term [32].

Government agencies, non-governmental organizations (NGOs), and other actors use the SL framework to propose and implement public policies oriented toward improving people's livelihoods in a sustainable manner, as well as to plan development programs [34].

\subsubsection{Sampling and Obtaining Data}

With the aim of evaluating the cattle-raising units of the Frailesca Highlands and Valley, we designed a comparative study of three cases: (I) peasant cattle raising of the Calzada Larga ejido in the Frailesca Valley; (II) peasant cattle raising of the Los Angeles ejido in the Frailesca Highlands, within the buffer zone of the REBISE; and (III) holistic cattle raising by farmers with private land ownership in the Frailesca Valley.

Information was obtained through direct observation of the cattle farms as well as an semi-structured interview [35] with 31 cattle farmers of the Calzada Larga ejido, 38 of the Los Angeles ejido, and six of the region's seven holistic cattle raisers.

\subsubsection{Analysis of Farmers' Livelihoods}

The interview addressed those components of the sustainable livelihoods framework described in Section 3.2.1 and allowed for describing the following aspects of the farmers' livelihoods: (I) capitals (Table 2); (II) livelihood strategies (evaluated based on agricultural as well as non-agricultural income sources); and III) farmers' perceptions of their vulnerability context and stressors affecting their farms (e.g., climatic effects, prices of products and inputs, community and organizational regulations). In order to calculate agricultural income, we asked farmers to report the yield for each agricultural product during the previous year, including products sold as well as those used for self-provisioning. In order to calculate agricultural income, we multiplied yield during the previous year by the price at which the farmer reported having sold the product. In order to calculate non-agricultural income, we asked farmers to report their weekly, monthly, or annual income from each source of non-agricultural income. Finally, total farm income was calculated as the sum of agricultural and non-agricultural income. In order to gather additional information, we also consulted secondary information sources.

For natural capital, the variable total number of animal units was obtained adding the animal units on the farm based on the following equivalences [36]: (I) cow with calf $=1.25$ animal units (AU); (II) pregnant cow = $1 \mathrm{AU}$; (III) non-pregnant cow = $0.9 \mathrm{AU}$; (IV) = 1.25 AU; (V) steer = $0.9 \mathrm{AU}$; (VI) heifer $=0.9 \mathrm{AU}$; (VII) weaned calf $=0.5 \mathrm{AU}$; (VIII) sheep $=0.2 \mathrm{UA}$; and (IX) horse $=1.0 \mathrm{AU}$. 
Table 2. Criteria and variables used to evaluate five capitals of cattle farms in three case studies in the dry tropics of Chiapas, Mexico.

\begin{tabular}{lll}
\hline \multicolumn{1}{c}{ Capitals } & \multicolumn{1}{c}{ Criteria } & \multicolumn{1}{c}{ Variables } \\
\hline Natural capital & $\begin{array}{l}\text { Surface area and land characteristics } \\
\text { (amount of flat and sloped land); presence } \\
\text { of forest patches on the farm as indicator of } \\
\text { agroecosystem health }\end{array}$ & $\begin{array}{l}\text { Total surface area (ha); flat surface area (ha); } \\
\text { forested surface area (ha) }\end{array}$ \\
\hline Physical capital & $\begin{array}{l}\text { Amount of cattle, infrastructure, and } \\
\text { machinery and other work equipment } \\
\text { owned }\end{array}$ & $\begin{array}{l}\text { Total animal units (AU); possession of } \\
\text { machinery, non-mechanized equipment, and } \\
\text { infrastructure (\% of maximum possessed }\end{array}$ \\
\hline Financial capital & Income from agriculture and wage labor & $\begin{array}{l}\text { Number of agricultural income sources; total } \\
\text { income (MX \$) }\end{array}$ \\
\hline Social capital & $\begin{array}{l}\text { Membership in farmers' organizations, } \\
\text { which impact communities' economic and } \\
\text { social processes; employment generated on } \\
\text { the farm for family members }\end{array}$ & $\begin{array}{l}\text { Number of organizations to which the farm } \\
\text { belongs; } \% \text { of farmers from each case study that } \\
\text { belong to at least one organizations; number of } \\
\text { family members working on the farm }\end{array}$ \\
\hline Human capital & $\begin{array}{l}\text { Formal educational level (elementary } \\
\text { school on); experience in and knowledge of } \\
\text { cattle raising; access to technical assistance } \\
\text { and training }\end{array}$ & $\begin{array}{l}\text { Farmers' formal education level (years); years } \\
\text { raising cattle; \% of farmers from each case } \\
\text { study with some level of technical assistance } \\
\text { and training }\end{array}$ \\
\hline
\end{tabular}

For physical capital, in order to construct the variables possession of non-mechanized equipment (sprayer, wheelbarrow), possession of infrastructure (corral, milking parlor, warehouse, sanitary equipment, electric fence), and possession of machinery (truck, hay-cutter, grain mill, feed mixer, mechanical milker, milk tank, tractor), the following steps were carried out: (I) for each farm, components of each of these three variables (non-mechanized equipment, infrastucture, machinery) were quantified; (II) maximum values per variable per case study were obtained; (III) in order to qualify each variable on a scale of $0 \%$ to $100 \%$, the maximum value (described in step II) was set as $100 \%$ and the value for each farm per variable per case study was extrapolated.

In order to determine the livelihood outcomes of the sustainable livelihoods framework, adaptability of the cattle farms was evaluated by constructing an index.

\subsubsection{Index of Adaptability}

According to Campbell et al. [37] an advantage of the capitals approach within the livelihoods analysis is that a wide range of information may be obtained to evaluate system performance. For the present study, based on the capitals, eight variables were integrated to construct an index of adaptability of the farms to multiple stressors.

In order to determine those variables that would integrate the index, we referred to other authors who have evaluated adaptive capacity of natural resource management systems (e.g., farming, forestry, and fishing) which have a similar focus to that of the present study as they also develop indicators based on analysis of livelihoods in order to evaluate systems' resilience and adaptive capacity [13,38-43]. Of those variables that the authors of these studies have used to evaluate farms' adaptive capacity, we included the following - which have different units of measure-in our index of adaptability: (I) total surface area (ha), (II) flat surface area (ha), (III) forested surface area (ha), (IV) diversity of agricultural activities (num. agricultural activities); (V) total income (MX \$); (VI) membership in farmers' organizations (num. organizations); (VII) farmers' formal education level (years); and (VIII) farmers' participation in training courses (\% who participate).

The units of measure of the eight variables selected were standardized to percentage values. For this, we determined that for each variable, the maximum value observed among all cattle-raising units evaluated would be $100 \%$. Table 3 presents an example. 
Table 3. Example of standardization of the variable total surface area (ha) to a percentage value in order to integrate its standardized value to the index of adaptability.

\begin{tabular}{ccc}
\hline Farm & Total Surface Area (ha) & Standardized Percentage Values ${ }^{* *}$ of Total Surface Area \\
\hline 1 & 32 & 59.3 \\
2 & 27 & 50 \\
3 & $54 *$ & 100 \\
4 & 40 & 74.1 \\
$\ldots$ & $\ldots$ & $\ldots$ \\
75 & 36 & 66.7 \\
\hline
\end{tabular}

* Farm 3 has the largest total surface area (54 ha); ${ }^{* *}$ Maximum value observed in farm $3(54$ ha) $=100 \%$, therefore we assigned corresponding values to the other farms.

The value of the index of adaptability of each cattle farm was the average of the standardized percentage values of the eight variables. In order to calculate the index, all standardized variables were given the same weight (12.5\%).

In order to contrast the three case studies, the average value of each of the eight variables and the value of the index of adaptability were calculated for each case study. Those variables of the index that appeared to most contribute to the index of adaptability in each case study were identified through "spider", or radar, diagrams.

\subsubsection{Statistical Analysis of Information}

Information was systematized in a data base and statistically analyzed using version 15.0 of the Statistical Package for Social Sciences (SPSS). Once normality in data distribution was verified, a contrast of means was carried out among the three groups of cattle farms evaluated using one-way analysis of variance (ANOVA). Variables showing significant differences in the ANOVA were submitted to Levene's homogeneity variances test. Depending on the results of this test, a posteriori contrasts (multiple comparisons) were carried out using Tukey's honest significant difference (HSD) method ( $p<0.05$; assuming equal variances) or the Games-Howell method ( $p<0.05$; assuming unequal variances) in order to identify among which groups statistical differences were found.

\section{Results and Discussion}

\subsection{Capitals}

Table 4 presents farm families' capitals and their corresponding variables in the three cases studied. Los Angeles farmers have intermediate levels for two of the three variables of natural capital. With respect to human capital, these farmers have the least $(p<0.05)$ formal education and training. Although they have a greater $(p<0.05)$ number of hectares than those of Calzada Larga, this land is more difficult to cultivate as most $(>95 \%)$ is sloped.

The landholdings of Los Angeles farmers include forest patches, which on average make up 10\% of total surface area. Vides [44], who carried out a study in 2011 on cattle farms in the Los Angeles ejido, reports that soils have a loamy-clayish-sandy texture; are highly compacted; have moderate levels of total nitrogen content $(0.11 \%)$ and organic matter $(2.6 \%)$; high acidity $(\mathrm{pH}=5.2)$; and low cation exchange capacity $(16.1 \mathrm{Cmol} / \mathrm{kg})$. These soil characteristics were recently corroborated with recent ECOSUR soil laboratory data [45] wich shows very acidic soils with low electrolytic conductivity capacity $(0.16 \mathrm{mS} / \mathrm{cm})$; moderate levels of total nitrogen and organic matter; nutrient deficiency $(\mathrm{k}, \mathrm{Ca}$, $\mathrm{Mg}, \mathrm{Z}, \mathrm{B}, \mathrm{Mn}$, and P); and lead contamination (288 ppm). With respect to soil microbiota Highlands soils had high levels of pathogens (Acinetobacter, Cercospora sp, Fusarium de la corona, Fusarium solani, Phytium Rhizoctonia, Penecillinum commune, and Puccinia-"roya") and low levels of beneficial organisms (Trichoderma harzianum, B. Subtilis, Azospirillum, Micorrizas, and Lecanicillium lecanii) [45]. 
Table 4. Average values ( \pm standard error) of variables that integrate five capitals of cattle farms in three case studies in the dry tropics of Chiapas, Mexico.

\begin{tabular}{|c|c|c|c|c|}
\hline & \multicolumn{3}{|c|}{ Frailesca Region } & \multirow[b]{3}{*}{ F; $p$-Value } \\
\hline & \multirow{2}{*}{$\begin{array}{c}\text { Highlands } \\
\text { Los Angeles }\end{array}$} & \multicolumn{2}{|c|}{ Valley } & \\
\hline & & Calzada Larga & Holistic Farms & \\
\hline Capitals & $n=38$ & $n=31$ & $n=6$ & \\
\hline \multicolumn{5}{|l|}{ Natural capital } \\
\hline Total surface area (ha) & $58.3^{\mathrm{b}}( \pm 8.1)$ & $16.3^{c}( \pm 1.7)$ & $112.7^{\mathrm{a}}( \pm 17.4)$ & $20.5 ; 0.0001$ \\
\hline Flat surface area (ha) & $1.6^{c}( \pm 0.3)$ & $9.7^{\mathrm{b}}( \pm 1.0)$ & $95.2^{\mathrm{a}}( \pm 17.3)$ & $161.2 ; 0.0001$ \\
\hline Forested surface area (ha) & $5.4( \pm 3.0)$ & $0.6( \pm 0.3)$ & $15( \pm 4.1)$ & 3.0; NS \\
\hline \multicolumn{5}{|l|}{ Physical capital } \\
\hline Total animal units (AU) & $28.9^{b}( \pm 3.3)$ & $31.2^{\mathrm{b}}( \pm 3.1)$ & $180.4^{\mathrm{a}}( \pm 28.1)$ & $94.1 ; 0.0001$ \\
\hline $\begin{array}{l}\text { Possession of non-mechanized equipment } \\
\text { (\% of maximum possessed) }\end{array}$ & $6.5^{\mathrm{c}}( \pm 1.0)$ & $19.0^{\mathrm{b}}( \pm 4.3)$ & $88.7^{\mathrm{a}}( \pm 8.6)$ & $58.8 ; 0.0001$ \\
\hline $\begin{array}{l}\text { Possession of infrastructure (\% of maximum } \\
\text { possessed) }\end{array}$ & $6.2^{c}( \pm 1.0)$ & $19.6^{\mathrm{b}}( \pm 3.4)$ & $83.3^{\mathrm{a}}( \pm 4.6)$ & $84.5 ; 0.0001$ \\
\hline $\begin{array}{l}\text { Possession of machinery (\% of maximum } \\
\text { possessed) }\end{array}$ & $10.3^{\mathrm{b}}( \pm 3.4)$ & $14.8^{\mathrm{b}}( \pm 4.3)$ & $98.3^{\mathrm{a}}( \pm 1.6)$ & $43.7 ; 0.0001$ \\
\hline \multicolumn{5}{|l|}{ Financial capital } \\
\hline $\begin{array}{l}\text { Diversity of agricultural income sources } \\
\text { (num. income sources) }\end{array}$ & $3.2^{\mathrm{a}}( \pm 0.2)$ & $1.4^{\mathrm{b}}( \pm 0.1)$ & $1.3^{b}( \pm 0.2)$ & $35.6 ; 0.0001$ \\
\hline Total income (MX \$) & $113,086^{\mathrm{c}}( \pm 10,816)$ & $244,138^{\text {b }}( \pm 32,739)$ & $1,529,718^{\text {a }}( \pm 413,185)$ & $60.0 ; 0.0001$ \\
\hline \multicolumn{5}{|l|}{ Social capital } \\
\hline $\begin{array}{l}\text { Per-farm membership in farmers' } \\
\text { organizations (num. organizations) }\end{array}$ & $1.13^{\mathrm{a}}( \pm 0.077)$ & $0.22^{b}( \pm 0.076)$ & $1.16^{\mathrm{a}}( \pm 0.16)$ & $37.2 ; 0.0001$ \\
\hline $\begin{array}{l}\text { Farmers/community belonging to farmers' } \\
\text { organizations }(\%)\end{array}$ & $92.1^{\mathrm{a}}( \pm 4,4)$ & $22.6^{\mathrm{b}}( \pm 7.6)$ & $100^{\mathrm{a}}( \pm 0.0)$ & $40.0 ; 0.0001$ \\
\hline \multicolumn{5}{|l|}{ Human capital } \\
\hline Family members (num.) & $4.9( \pm 0.3)$ & $4.0( \pm 0.3)$ & $4.5( \pm 0.6)$ & 2.50; N.S \\
\hline Family labor (num. family members) & $1.8^{\mathrm{a}}( \pm 0.2)$ & $1.2^{\mathrm{b}}( \pm 0.1)$ & $2.2^{\mathrm{a}}( \pm 0.3)$ & $5.8 ; 0.001$ \\
\hline Farmer's formal education level (years) & $4.2^{\mathrm{b}}( \pm 0.6)$ & $3.5^{\mathrm{b}}( \pm 0.7)$ & $12.7^{\mathrm{a}}( \pm 0.9)$ & $16.3 ; 0.0001$ \\
\hline Time raising cattle (years) & $15.4^{\mathrm{b}}( \pm 1.40)$ & $15.9^{\mathrm{b}}( \pm 1.11)$ & $31.8^{\mathrm{a}}( \pm 3.70)$ & $12.1 ; 0.0001$ \\
\hline $\begin{array}{l}\text { Farmers that have received some technical } \\
\text { assistance and training (\% who participate) }\end{array}$ & $31.6^{\mathrm{b}}( \pm 7.64)$ & $12.9^{b}( \pm 6.12)$ & $100.0^{\mathrm{a}}( \pm 0.0)$ & $11.8 ; 0.0001$ \\
\hline
\end{tabular}

Different letters $\left({ }^{a}, b, c\right)$ in the same row indicate significant differences $(p<0.05)$.

Los Angeles farmers make more $(p<0.05)$ diversified use of their land than do those of both other groups: besides raising cattle on $81 \%$ of their land (on average), they cultivate maize (on $2.8 \%$ of their land), beans $(0.7 \%)$, and shade coffee (1.3\%). Thirty-five of the 38 Los Angeles farmers interviewed belong to farmers' organizations. With respect to human capital, Los Angeles farmers have the greatest $(p>0.05)$ family members, and they have the lowest $(p<0.05)$ time raising cattle.

Calzada Larga farmers generally have the lowest levels of most capitals; they have the least $(p<0.05)$ surface area, although a majority of their land is flat $(60 \%)$ and well-suited to agriculture. Calzada Larga farmers have a higher level $(p<0.05)$ of flat surface area and total family income than do those of Los Angeles. Calzada Larga farmers have a low percentage $(p>0.05)$ of forest cover in their agroecosystems $(<5 \%)$. Aside from the low level of tree cover, recent evidence shows poor soil quality in Calzada Larga farms [45] as they have low levels of organic matter (approximately $36 \%$ of humic acids and 33\% carboxylic acids); low microbiota activity, in particular nitrogen fixing bacteria (Azospirillum, Azotobacter, and Rhizobium) and mycohrrizal (Pseudomonas, Bauveria bassiana, Bacillus Thuringensis, and Lecanicillium lecanii) which act as biological pathogen controls; by contrast, high levels of the soil pathogens Acinetobacter and Ergot are found. Calzada Larga soil has low levels of the cation exchange capacity (electrolityc conductivity: $0.12 \mathrm{mS} / \mathrm{cm}$ ). Nutrients found at moderate levels are $\mathrm{k}, \mathrm{Ca}, \mathrm{Mg}, \mathrm{Cu}, \mathrm{Mn}, \mathrm{B}$, and $\mathrm{Mo}$; those found at low levels are $\mathrm{Fe}, \mathrm{N}$, and $\mathrm{Zn}$; and soil is highly contaminated by lead (288 ppm) [45].

With respect to social capital, only seven of the Calzada Larga farmers interviewed belong to farmers' organizations.

Holistic cattle raisers have higher levels of all capitals than do those of both ejidos. The holistic farmers in general have a greater $(p<0.05)$ surface areas of land than do the other two groups of farmers, and their land is of higher quality: the majority $(83 \%)$ is flat with deep soil. Alfaro et al. [18] carried 
out a study on these seven holistic farms, reporting a loamy-clayish-sandy soil texture; acidic soils $(\mathrm{pH}=5.7)$; moderate levels of organic matter $(3.3 \%)$ and total nitrogen content $(0.16 \%)$; and acceptable phosphorous levels $(59.9 \mathrm{mg} / \mathrm{kg})$ - greater $(p<0.05)$ than that observed on conventional ranches by the same author $(35.3 \mathrm{mg} / \mathrm{kg})$.

Farmers of all three cases use over $80 \%$ of their land for cattle raising, with the holistic farmers using the highest $(p>0.05)$ proportion of their land for this purpose. These farmers own the greatest $(p<0.05)$ surface area of forest; each has over 10\% of their agroecosystem forested. Each also owns more $(p<0.05)$ animal units (cattle and horses) than any of the farmers of the other two groups. Furthermore, in general they own more $(p<0.05)$ hand tools (e.g., machete, hoe, shovel), non-mechanized equipment (sprayer, wheelbarrow), infrastructure (corral, milking parlor, warehouses, sanitary equipment, electric fence), and machinery (truck, hay-cutter, grain mill, feed mixer, mechanical milker, milk tank, tractor) than the farmers of both ejidos. All of the holistic farmers belong to farmers' organizations.

With respect to human capital, the holistic farmers have the greatest $(p<0.05)$ formal educational level and the most $(p<0.05)$ years raising cattle, and have received the most $(p<0.05)$ technical assistance and training.

\subsection{Livelihood Strategies}

The current livelihood strategies of the farm families of the three case studies are differentiated based on the percentage contribution of each income source to their total income [46]. Table 5 and Figure 3 presents the income strategies of the farm families of the three cases evaluated.

Table 5. Income strategies (MX \$) of cattle-raising families of three case studies in the dry tropics of Chiapas, Mexico.

\begin{tabular}{lcccc}
\hline \multicolumn{5}{c}{ Frailesca Region } \\
\hline & Highlands & \multicolumn{3}{c}{ Valley } \\
\hline & Los Angeles & Calzada Larga & Holistic Farms & F; $p$-Value \\
\hline Strategies & $n=38$ & $n=31$ & $n=6$ & \\
\hline Income from staple foods & $21,207^{\mathrm{a}}$ & $22,995^{\mathrm{a}}$ & $0.0^{\mathrm{b}}$ & $8.2 ; 0.0001$ \\
Income from shade coffee & $3516^{\mathrm{a}}$ & $0.0^{\mathrm{b}}$ & $0.0^{\mathrm{b}}$ & $1.5 ; \mathrm{NS}$ \\
Income from cattle raising & $45,401^{\mathrm{c}}$ & $202,116^{\mathrm{b}}$ & $1,248,382^{\mathrm{a}}$ & $53.7 ; 0.0001$ \\
$\quad$ Subtotal of agricultural income & $70,124^{\mathrm{c}}$ & $225,111^{\mathrm{b}}$ & $1,248,382^{\mathrm{a}}$ & $51.2 ; 0.0001$ \\
Income from non-agricultural labor & $11,015^{\mathrm{b}}$ & $1529^{\mathrm{b}}$ & $156,667^{\mathrm{a}}$ & $11.1 ; 0.0001$ \\
Income from welfare subsidies & $4967^{\mathrm{a}}$ & $4280^{\mathrm{a}}$ & $0.0^{\mathrm{b}}$ & $7.7 ; 0.0001$ \\
Income from agricultural subsidies & $18,375^{\mathrm{b}}$ & $8883^{\mathrm{c}}$ & $33,003^{\mathrm{a}}$ & $15.9 ; 0.0001$ \\
Income from loans & $1000^{\mathrm{b}}$ & $4335^{\mathrm{b}}$ & $91,666^{\mathrm{a}}$ & $14.7 ; 0.0001$ \\
Income from remittances & $7605^{\mathrm{a}}$ & $0.0^{\mathrm{b}}$ & $0.0^{\mathrm{b}}$ & $2.6 ; \mathrm{NS}$ \\
$\quad$ Subtotal of non-agricultural income & $42,963^{\mathrm{b}}$ & $19,027^{\mathrm{b}}$ & $281,336^{\mathrm{a}}$ & $14.3 ; 0.0001$ \\
Total Income & $113,087^{\mathrm{b}}$ & $244,138^{\mathrm{b}}$ & $1,529,718^{\mathrm{a}}$ & $60.0 ; 0.0001$ \\
Per capita income & $26,420^{\mathrm{c}}$ & $71,488^{\mathrm{b}}$ & $478,417^{\mathrm{a}}$ & \\
\hline
\end{tabular}

1. Different letters $\left({ }^{a}, b, c\right)$ in the same row indicate significant differences $(p<0.05)$. 2. Income from production of staple foods (maize and beans) includes monetary as well as non-monetary income (self-provisioning). 3. Income from non-agricultural labor includes paid work (such as construction and driving public transport) and income from self-employment in commerce and services (such as grocery stores, tortilla shops, butcher shops, and restaurants). 4. Welfare subsidies are provided through the Mexican government programs Oportunidades, Nuevo Amanecer, and Setenta y Mas, the latter two of which are provided to senior citizens. 5. Agricultural subsidies are provided through the Program of Direct Support to maize production and cattle-raising (PROCAMPO and PROGAN in Spanish respectively). 6. For all strategies, income refers to gross income.

Families of the Los Angeles ejido receive a majority of their income from agricultural activities (staple foods, shade coffee and cattle-raising), although their livelihood strategy is somewhat more diversified than those of the other two cases, consisting of nine income sources. Cultivation of staple foods (maize and beans principally for self-provisioning) provides over $20 \%$ of income of Los Angeles farm families. Eighteen percent of Los Angeles farmers also cultivate shade-grown coffee, as their 
land is suited to this crop. The second most significant income source for Los Angeles farmers $(p<0.05)$ - after agricultural income-is government agricultural and welfare subsidies.

Table 5 shows that almost $80 \%$ of income of families of both cases in the valley comes from cattle-raising. While the holistic farmers have four income sources, their strategy is the most specialized, as cattle-raising is their only agricultural activity. Holistic farmers complement their income by owning small businesses which are not related to agriculture, as well as with loans and agricultural subsidies.

Calzada Larga farmers follow a somewhat specialized income strategy, depending on six income sources. With respect to crop agriculture, they devote small plots of land to maize (8.2\%), beans $(0.4 \%)$, and sorghum $(0.5 \%)$; as with their pastures, they also use high levels of external inputs for these crops. Following agricultural income, those income sources which most contribute to their livelihood strategy are government agricultural and welfare subsidies, and to a lesser extent loans and non-agricultural labor.

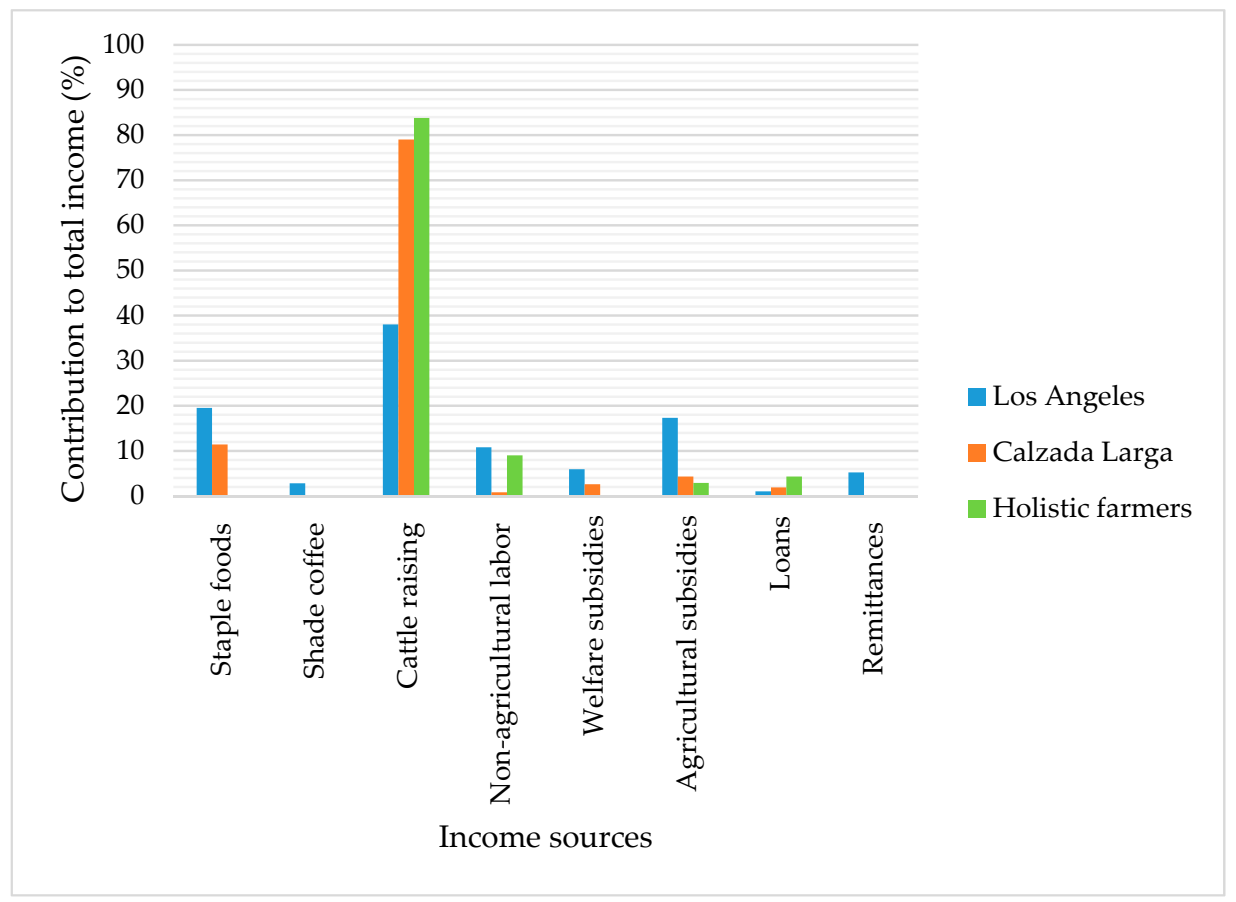

Figure 3. Income sources of cattle-raising families of three case studies in the dry tropics of Chiapas, Mexico.

The holistic farmers have the highest average total income, as well as the highest average income from cattle-raising $(p<0.05)$. Holistic farmers' average income is approximately six times greater than that of Calzada Larga and 15 times that of Los Angeles farmers.

Analysis of the composition of farm families' income allowed for identifying the livelihood strategies of the families of the three case studies; the most specialized were the holistic farmers, and the most diversified those of the Los Angeles ejido. Given that these strategies are associated with the particular forms of practicing cattle raising in each case study described in Section 2.1, we may define three types of strategies: (I) strategy specialized in holistic cattle-raising; (II) cattle-raising-crop cultivation strategy with high use of purchased inputs; and (III) diversified strategy including extensive livestock raising.

\subsection{Index of Adaptability of Cattle Farms to Multiple Stressors}

Figure 4 compares the values of the index of adaptability of the three cases evaluated. Holistic farms have the greatest average index of adaptability $(p<0.05)$, followed by Los Angeles farms, and lastly the Calzada Larga farms. 


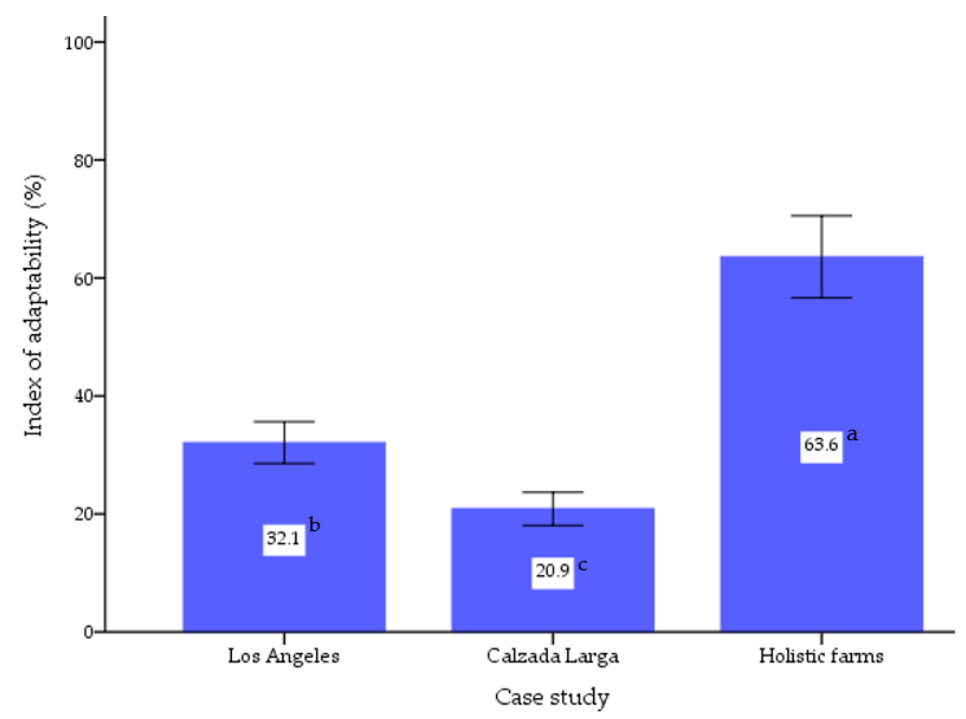

Figure 4. Index of adaptability of cattle farms to multiple stressors in three case studies in the dry tropics of Chiapas, Mexico. Bars represent averages and lines represent standard error. Different letters $(\mathrm{a}, \mathrm{b}, \mathrm{c})$ next to the averages indicate significant differences $(p<0.05)$.

For Los Angeles farms, the value of the index of adaptability ranged from 11.1 to $68.3 \%$; for Calzada Larga cattle farms from 9.6 to $39.8 \%$, and for the holistic farms from 58 to $79.8 \%$.

Figure 5 shows those indicators which most contributed to the final value of the index for each case evaluated. For the Los Angeles ejido, those variables which most contributed to the index of adaptability were belonging to farmers' organizations and diversity of agricultural activities. Following these were the variables farmers' participation in training courses and total surface area, both with an average value of approximately $30 \%$.

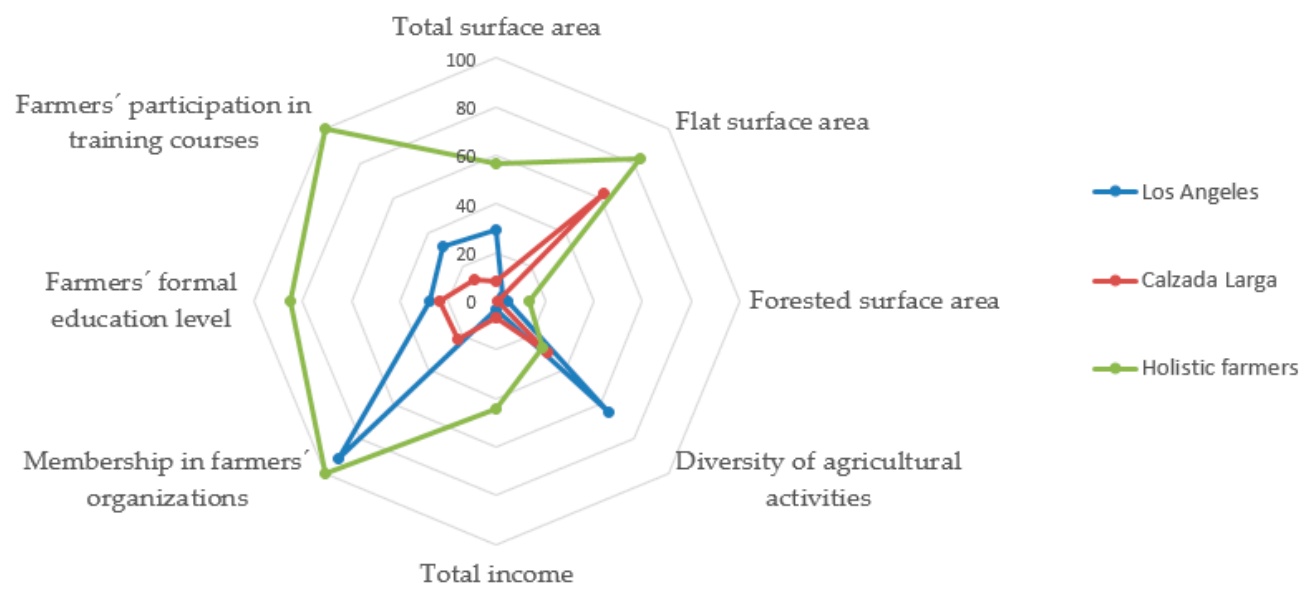

Figure 5. Radial diagram that shows average values of the eight indicators which integrate the index of adaptability of cattle farms to multiple stressors in three case studies in the dry tropics of Chiapas, Mexico.

Calzada Larga farmers, who had the lowest level of adaptability, also had low levels for all variables of the index. The only variable with a high level is flat surface area, while diversity of agricultural activities ranked second, although it had a much lower value (less than $20 \%$ ).

In the case of the holistic farmers, four variables most contributed to their index of adaptability: (I) membership in farmers' organizations; (II) farmers' participation in training courses; (III) flat surface area; and (IV) farmers' formal education level. 
Using the sustainable livelihoods analytical framework to measure adaptability allows for a multi-dimensional analysis which transcends those evaluations limited to analyzing particular aspects of a given system $[43,47,48]$.

Several studies have used the sustainable livelihoods framework to generate indicators and evaluate resilience and adaptability of agricultural systems. For example, Quand [43] proposes the household livelihood resilience approach to evaluate resilience through quantitative indicators as well as a few "subjective" indicators. Other studies have evaluated adaptability and resilience on a community level $[48,49]$. There is a need to adjust indicators of adaptability to the specific geographic and social context [50].

\subsection{Livelihood Strategies and Adaptability}

Farmers worldwide have long been adapting their livelihood strategies to changing stressors. Literature regarding rural livelihoods in the face of climate change has characterized the ways in which multiple stressors affect people's livelihoods and how families adapt, pointing out interconnections among livelihood strategies, capitals, and multiple stressors [51].

The situation of Calzada Larga farmers is similar to that of many small-scale farmers in the Mexican tropics whose livelihood strategy is based on agricultural intensification through use of agrochemicals given a lack of opportunities for non-agricultural employment. The situation of such farmers is largely the result of local and national public policy, the market, interests of transnational corporations, and policies and practices of international financial and development organizations, often under the guise of modernization and combating poverty [52]. Based on the case of Calzada Larga, we deduce that the strategy of these farmers is a result of their lack of land, deforestation, low income levels, a lack of organization, low formal educational levels, and low levels of technical assistance and training. Given this context, the capacity of response of small-scale farmers to multiple stressors is low, and coping with stressors may erode their resources and increase their exposure and/or sensitivity to other stressors, although they may also be able to reallocate those resources they have available to be able to respond to future stressors [8].

The case of the Los Angeles ejido is relatively similar to that of Calzada Larga with respect to farmers' low level of formal education and farm families' low incomes. Families of both communities are affected by global neoliberal economic tendencies. Furthermore, farmers in buffer zones of natural protected areas also confront restrictive regulations regarding use of natural resources in their communities. Efforts of government agencies and NGOs to foment conservation and/or agriculture also generate opportunities for the farmers of this region; as a result, those of the Los Angeles ejido have a high level of membership in farmers' organizations and access to training, which has led them to carry out a diversity of agricultural activities. Furthermore, having a diversity of income sources is critical for adaptability of farm systems as it contributes to accumulation of resources which help to reduce risks during times of crisis. As has been reported by other studies of farmers located in natural protected areas e.g., [53], farm families' who belong to farmers' organizations and who carry out a variety of agricultural activities appear to have a higher level of adaptability. Abreu et al. [54] points out that social capital is a valuable resource as it facilitates farmers' economic activities and provides them with access to opportunities which may benefit their livelihood strategies.

The holistic farms have the highest rate of adaptability. As these farmers have the largest surface area and highest quality land, they have been able to increase all their capitals, which has favored their rate of adaptability. Their high level of social capital is largely due to their membership in formal and informal farmers' organizations, which has facilitated access to subsidies as well as technical assistance and training. Access to farm subsidies has increased their physical capital, as they have acquired agricultural equipment, while technical assistance and training has increased their human capital, which in turn has improved their natural capital, as they have adopted agroecological practices such as silvopastoral systems, use of green manures, and conservation of forest patches. 
The higher level of formal education of holistic farmers' as compared to that of farmers of both ejidos has contributed to the greater level adaptability of their farms. A study in Bangladesh [41] found that families with greater formal educational levels were more likely to take on and adapt sustainable agricultural practices.

The following sections present possible scenarios involving the two principal stress factors addressed in the cases studied, and provide specific recommendations for the cattle-raising systems of the study area so that they may be able to reduce their vulnerability and increase their level of adaptability in the face of multiple stressors.

\subsection{Approaches to Adapting Cattle Farms to Multiple Stressors}

Aside from the communities' levels of capitals, an important aspect of analysis of adaptability using the sustainable livelihood approach is analyzing farmers' access to resources and their ability to use these resources to undertake strategies of adaptation [18]. This may involve local organizations providing training and funding to improve their production systems. Government agencies may also foment adaptation strategies for farmers by modifying their policies (planned adaptation).

\subsubsection{Scenarios and Strategies for Facing the Climatic Stress Factor of Drought}

Estimations reported by the Intergovernmental Panel on Climate Change [55] indicate that by 2100, Earth's temperature could increase by $0.3^{\circ} \mathrm{C}$ to $4.8^{\circ} \mathrm{C}$. It is predicted that in tropical dry regions, high temperature increases (next to the $4.8^{\circ}$ ) will reduce agricultural productivity, and Latin America is expected to face increased drought as well as loss of forests and biodiversity. In particular, hydric stress would provoke a crisis in fodder production and, therefore, lead to decreased livestock production [56].

Given this scenario, if Calzada Larga farmers continue their current practices, they would likely increase their stocking rate and purchase more inputs (fodder, chicken manure, agrochemicals) to maintain production levels. Nevertheless, given scarcity of land and deforestation, these responses would likely be insufficient and could even increase farmers' vulnerability to future disturbances as a result of soil degradation and environmental contamination, which would compromise their survival as farmers.

For Los Angeles farmers who follow an extensive cattle-raising strategy with low use of external inputs, in the case of an increase in hydric stress in their agroecosystems, only wealthier farmers would be able to purchase enough fodder to feed their cattle during droughts. Cattle mortality would likely increase during droughts due to malnutrition, especially for poorer farmers. Given such a scenario, farmers would likely reduce stocking rate, and cattle-raising would no longer be profitable.

The holistic cattle raisers would likely be the least affected in the event of increased drought, as they have been implementing sustainable techniques in their agroecosystems such as maintaining forest patches, conserving trees in pastures, and planting fodder for cutting. Furthermore, they have the greatest ability to invest in improvements on their farms-for example establishing irrigation systems, which could mitigate the effects of climate change.

The holistic farmers' relative advantages aside, the generally discouraging future scenario demonstrates the need for farmers of all three cases to implement sustainable livestock-raising practices that could help them face crises provoked by drought. One viable alternative for all three cases studied is implementation of silvopastoral systems.

Silvopastoral systems—or agroforestry systems with a livestock component—consist of a variety of forms of land use and agronomic arrangements combining food crops; grasses, shrubs, and trees for fodder and other purposes; and animals, simultaneously or successively [57].

The many types of silvopastoral systems contribute a variety of livestock products, including meat, milk, fiber, manure, timber, and firewood, as well as animal traction. Silvopastoral systems allow for adapting to-while also mitigating-climate change, as they increase tree and shrub cover, provide shade thereby reducing climate stress, increase pasture yield and quality, increase fodder nutrient levels and efficiency of use, fix atmospheric nitrogen in the soil, and allow for reducing use 
of chemical fertilizers [58,59]. They also provide a variety of environmental services, such as climate regulation, as well as regulation of $\mathrm{CO}_{2}$, nitrous oxide, and methane emissions, and contribute to nutrient recycling, restauration of degraded soils, biodiversity conservation, watershed protection, improvement of water quality, increased connectivity among ecosystems, and scenic beauty [59].

Aside from implementing silvopastoral systems, Murgueitio et al. [60] propose the following to adapt livestock agroecosystems to-and mitigate-climate change: (I) plan use of farmland, for example using the most pronounced slopes for mixed cropping of fodder and trees, forestry, and/or conservation areas, (II) conserve, store, and efficiently use water, (III) implement soil conservation practices, (IV) increase tree, shrub, and weed cover, (V) introduce locally adapted plant varieties and animal breeds, (VI) implement agroecological practices that allow for reducing use of agrochemicals and petroleum, and (VII) avoid unsustainable practices such as controlled burning which leads to deforestation and soil degradation.

In all three cases studied, silvopastoral systems could be developed to suit farmers' needs and expectations by making use of local resources. However, it could be more difficult to for Calzada Larga farmers to transition to silvopastoral systems, as farmers with fewer economic resources are more reluctant to invest in long-term benefits [61].

Mexican government agencies that promote agriculture and conservation could provide incentives to farmers to develop silvopastoral systems in exchange for their ecological benefits, as some nations have done with respect to environmental services provided by silvopastoral systems and use of other sustainable agricultural techniques.

\subsubsection{Scenarios and Actions to Confront the Economic Stress Factor of Undesirable Market Conditions}

Given the likelihood that prices of livestock products continue to decrease and input prices increase, farmers face an economic challenge. In such a scenario, as Calzada Larga farmers are more dependent on external inputs than the farmers of the other two cases, they would likely be more affected as $80 \%$ of their income-with which they are able to reinvest in their current farm system by purchasing inputs-comes from cattle raising.

Enhancing social capital is key to improving farmers' collective capacity to respond to market adversities. Upon increasing their social capital, farmers would increase their capacity to negotiate with other actors involved in marketing chains for their products. Furthermore, they would increase their capacity to strengthen the rest of their capital [62]. As Dedieu points out [63], construction of social networks plays a key role in adaptive capacity.

By enhancing their physical capital, farmers with few economic resources, such as those of both ejidos in the present study, may reduce their disadvantage in marketing relationships with intermediaries who often control product prices based on quality. For example, farmers' organizations may fund construction of roofed areas with cement floors which are protected from rain and mud and, therefore, improve milking hygiene and safety. These organizations may also fund farmers' efforts to add value to products-for example by purchasing equipment and building facilities to make cheese. Such initiatives may also be financed by the farmers themselves through cooperatives, or with the support of government agencies.

Farmers' organizations may influence the government to carry out regional projects which would improve communities' physical capital, such as highway construction to facilitate marketing products [64]. This would be particularly useful for Los Angeles farmers as deficient highway infrastructure makes marketing milk difficult.

An increase in consumer awareness of health, illnesses associated with dietary and other lifestyle changes, and emerging zoonosis-as well as concern regarding methods of food production; the environment; animal well-being; and use of antibiotics, hormones and other growth promoters-may increase the demand for healthy (e.g., organic) animal products.

Traditional grazing as a main source of fodder in tropical southeastern Mexico favors desirable fatty acids in dairy products—-for example, monounsaturated rather than saturated fatty acids [60]. 
There is a need for additional studies that confirm the relationship between grazing and production of healthier fatty acids given that many consumers today avoid high concentrations of saturated fatty acids, as they have been found to be associated with heart disease and strokes [65]. As in the three cases evaluated in the present study, the comparative nutritional advantage of products from livestock systems in which cattle are grazed and the increase in demand for such products could be an opportunity for farmers to enter new market niches.

Entering organic markets requires complying with standards regarding animal feeding, sustainable grassland management, ecological pest and weed control in pastures, ecological fertilization, natural animal reproduction, animal well-being, use of medications, agrifood safety, and ecological farm management. Many of these areas require farmer consciousness-raising and training, which involves building human capital. There is also a need for a high level of social capital in order to collectively undertake the process of transitioning to-and marketing of-organic or ecological products. There is also a need for government agencies to adapt their program guidelines-which generally favor large-scale farming - to the context and needs of small-scale farms [66].

Los Angeles farmers, who raise livestock within a natural protected area and use few chemical inputs, could find it easier than the Calzada Larga farmers to enter the organic niche market. For the same reason, they may be able to receive support from conservation-oriented government agencies and NGOs. Holistic livestock management is highly compatible with the organic farming model, as it involves agroecological technologies. However, unlike those of Los Angeles, the holistic farmers are located in a region in which many farmers use high levels of chemical inputs, which could make it difficult for them to enter ecological markets.

\section{Conclusions}

Three livelihood strategies were identified: (I) strategy specialized in holistic cattle-raising; (II) cattle-raising-crop cultivation strategy with high use of purchased inputs; and (III) diversified strategy including extensive livestock raising.

The index of adaptability of cattle-raising to multiple stressors was greater for the holistic farms located in the Frailesca Valley, followed by those of the Los Angeles ejido of the highlands, and lastly those of Calzada Larga in the valley. The low level of adaptability of Calzada Larga farmers is due to the fact that they have little land; their agroecosystems are deforested; their incomes are low; and they have low levels of formal education, technical assistance, and training. The holistic farmers' situation is quite the opposite, as reflected in their high value for the index of adaptability. Given the possibility of increased drought and market crises, under their current production system Calzada Larga farmers would have to further increase agrochemical use to sustain productivity, which could risk their economic survival and deteriorate their farmland.

This study reveals the need to implement adaptation strategies—such as organic cattle raising and silvopastoral systems-that reduce families' vulnerability and increase their adaptability to multiple stressors. This would require public policy which responds to the conditions of the most vulnerable farmers.

Author Contributions: Conceptualization: J.R.A.-J., J.N.-T., M.R.P.-V., F.G.-H. and L.A.P.-F.; methodology_ J.R.A.-J., J.N.-T., M.R.P.-V., F.G.-H. and L.A.P.-F.; software: J.R.A.-J., J.N.-T., M.R.P.-V., F.G.-H. and L.A.P.-F.; validation: J.R.A.-J., J.N.-T., M.R.P.-V., F.G.-H. and L.A.P.-F.; formal analysis: J.R.A.-J., J.N.-T., M.R.P.-V., F.G.-H. and L.A.P.-F.; investigation: J.R.A.-J., J.N.-T., M.R.P.-V., F.G.-H. and L.A.P.-F.; resources: J.R.A.-J., J.N.-T., M.R.P.-V., F.G.-H. and L.A.P.-F.; data curation: J.R.A.-J., J.N.-T., M.R.P.-V., F.G.-H. and L.A.P.-F.; writing—original draft preparation: J.R.A.-J., J.N.-T., M.R.P.-V., F.G.-H. and L.A.P.-F.; writing-review and editing: J.R.A.-J., J.N.-T., M.R.P.-V., F.G.-H. and L.A.P.-F.; visualization: J.R.A.-J., J.N.-T., M.R.P.-V., F.G.-H. and L.A.P.-F.; supervision: J.R.A.-J., J.N.-T., M.R.P.-V., F.G.-H. and L.A.P.-F.; project administration: J.R.A.-J., J.N.-T., M.R.P.-V., F.G.-H. and L.A.P.-F.; funding acquisition: J.N.-T.

Funding: This study was funded by the project "Family Farming: Facing the Complexity of Adaptation to the Globalized Context", coordinated by Dr. Luis García Barrios of ECOSUR.

Acknowledgments: We thank Ann Greenberg for support in translating and reviewing the manuscript, and the farmers of the Frailesca region of Chiapas for support during fieldwork. 
Conflicts of Interest: The authors declare no conflict of interest.

\section{References}

1. FAO. La Ganadería y sus Desafíos en América Latina y el Caribe. 2014. Available online: http:/ /www.fao. org/agronoticias/agro-editorial/detalle/en/c/237808/ (accessed on 16 March 2016).

2. Steinfeld, H.; Gerber, P.; Wassenaar, T.; Castel, V.; Rosales, M.; de Haan, C. Livestock's Long Shadow, Environmental Issues and Options; LEAD-FAO: Rome, Italy, 2006.

3. COLPOS. Estudio y Análisis del Mercado de los Productos del Sistema Bovinos Doble Propósito en el Estado de Veracruz; Colegio de Postgraduados: Veracruz, Mexico, 2010; p. 85. (In Spanish)

4. SIAP. Sistema de Información Agroalimentaria y Pesquera. 2012. Available online: https://www.gob.mx/ siap (accessed on 13 August 2014).

5. IPCC. Fourth Assessment Report; Intergovernmental Panel on Climate Change: Geneva, Switzerland, 2007.

6. IPCC. Appendix II: Glossary. In Climate Change 2014: Synthesis Report; Mach, K.J., Planton, S., von Stechow, C., Eds.; Contribution of Working Groups I, II and III to the Fifth Assessment Report of the Intergovernmental Panel on Climate Change; IPCC: Geneva, Switzerland, 2014; pp. 117-130. Available online: https://www. ipcc.ch/pdf/assessment-report/ar5/syr/AR5_SYR_FINAL_Annexes.pdf (accessed on 25 July 2017).

7. McDowell, R.W. Environmental Impacts of Pasture-Based Farming; CAB International: London, UK, 2008; p. 298.

8. Belliveau, S.; Smit, B.; Bradshaw, B. Multiple exposures and dynamic vulnerability: Evidence from the grape industry in the Okanagan Valley, Canada. Glob. Environ. Chang. 2006, 16, 364-378. [CrossRef]

9. O'Brien, K.; Leichenko, R. Double exposure: Assessing the impacts of climate change within the context of economic globalization. Glob. Environ. Chang. 2000, 10, 221-232. [CrossRef]

10. Adger, W.N. Vulnerability. Glob. Environ. Chang. 2006, 16, 268-281. [CrossRef]

11. Smit, B.; Wandel, J. Adaptation, adaptive capacity and vulnerability. Glob. Environ. Chang. 2006, 16, $282-292$. [CrossRef]

12. Smit, B.; Burton, I.; Klein, R.J.T.; Wandel, J. An anatomy of adaptation to climate change and variability. Clim. Chang. 2000, 45, 223-251. [CrossRef]

13. Nelson, R.; Kokic, P.; Crimp, S.; Martin, P.; Meinke, H.; Howden, S.M.; Nidumolu, U. The vulnerability of Australian rural communities to climate variability and change: Part II-Integrating impacts with adaptive capacity. Environ. Sci. Policy 2010, 13, 18-27. [CrossRef]

14. Olsson, P.; Folke, C.; Berkes, F. Adaptive co-management for building resilience in social ecological systems. Environ. Manag. 2004, 34, 75-90. [CrossRef] [PubMed]

15. Reyes, R.M. El Reparto de Tierras y la Política Agraria en Chiapas 1914-1988; Anexos estadísticos; UNAM: Mexico City, Mexico, 1992. (In Spanish)

16. INEGI. Carta Edafologica en Escala 1:250,000; Instituto Nacional de Estadistica y Geografia; INEGI Publications: Mexico city, Mexico, 1985. (In Spanish)

17. McCune, N.M.; Guevara, H.F.; Nahed-Toral, J.; Mendoza-Nazar, P.; Ovando, C.; Ruiz, S.B.; Medina, S.L. Social-Ecological Resilience and Maize Farming in Chiapas, Mexico. In Sustainable Development-Authoritative and Leading Edge Content for Environmental Management; Sime Curkovic: Rijeka, Croatia, 2012; pp. 485-512.

18. Alfaro, R.; Diemont, S.; Ferguson, B.; Martin, J.F.; Nahed, J.; Álvarez, D.; Pinto, R. Steps toward sustainable ranching: An emergy evaluation of conventional and holistic management in Chiapas, Mexico. Agric. Syst. 2010, 103, 639-646. [CrossRef]

19. Savory, A.; Butterfield, J. Holistic Management: A New Framework for Decision Making; Island Press: Washington, DC, USA, 1999; p. 618.

20. Wadsworth, J. Dual purpuse cattle production: A system overview. In Dual Purpose Cattle Production Research; Anderson, S., Wadsworth, J., Eds.; International Workshop, IFS-FMVZ-UADY: Mérida, Mexico, 1992; pp. 2-27.

21. Carabias, J.; Landa, R.; Collado, J.; Martínez, P. Agua, Medio Ambiente y Sociedad. Hacia la Gestión Integral de Recursos Hídricos en México; UNAM, El Colegio de México, Fundación Gonzalo Río Arronte: Mexico City, Mexico, 2005; p. 221. (In Spanish)

22. Ramos, S.; Morales, H. Escenarios Climáticos Para el Estado de Chiapas; Universidad de Ciencias y Artes de Chiapas: Tuxtla Gutierrez, Mexico, 2010; p. 196. (In Spanish) 
23. Magaña, R.V.O. Los Impactos de "El Niño" en México; Centro de Ciencias de la Atmosfera, UNAM, Dirección General de Protección Civil, Secretaria de Gobernación: Mexico City, Mexico, 1999; p. 229. (In Spanish)

24. Rueda, O.; Cuartas, C.; Naranjo, J.; Córdoba, C.; Murgueitio, E.; Anzola, H. Comportamiento de variables climáticas durante estaciones secas y de lluvia, bajo influencia del ENSO 2009-2010 (El Niño) y 2010-2011 (La Niña) dentro y fuera de sistemas silvopastoriles intensivos en el Caribe seco de Colombia. Rev. Colom. Cienc. Ресua. 2011, 24, 512. (In Spanish)

25. Nardone, A.; Ronchi, B.; Lacetera, N.; Ranieri, M.S.; Bernabucci, U. Effects of climate changes on animal production and sustainability of livestock systems. Livest. Sci. 2010, 130, 57-69. [CrossRef]

26. USDA. Mexico: Market Concentration in Selected Agricultural and Food Subsectors. Global Agricultural Information Network Report No. MX1042; 2011. Available online: http://gain.fas.usda.gov/Recent $\%$ 20gain\%20Publications /Market\%20Concentration\%20in\%20Selected\%20Agricultural\%20and\%20Food\% 20Subsectors_Mexico_Mexico_5-25-2011.pdf (accessed on 14 October 2017).

27. Cavallotti, B. Ganadería bovina de carne y leche. Problemática y alternativas. El Cotid. 2014, 188, 95-102. (In Spanish)

28. García, E. Modificaciones al Sistema de Clasificación Climática de Köppen; Serie de libros No. 6; Instituto de Geografía de la Universidad Autónoma de México: Mexico city, Mexico, 2004; p. 90. (In Spanish)

29. SEPLAN. Agenda Estadística de Chiapas; Secretaría de Planeación; Gobierno del estado de Chiapas: Tuxtla Gutierrez, Mexico, 2000. (In Spanish)

30. INE. Programa de Manejo de la Reserva de la Biosfera La Sepultura; Instituto Nacional de Ecología: Mexico city, Mexico, 1999; p. 249. (In Spanish)

31. DFID. Sustainable Livelihoods Guidance Sheets; Emergency Nutrition Network (ENN); British Department for International Development: Oxford, UK, 1999.

32. Chambers, R.; Conway, G.R. Sustainable Rural Livelihoods: Practical Concepts for the 21st Century; Discussion Paper 296; Institute of Development Studies: Brighton, UK, 1992.

33. Adato, M.; Meizen-Dick, R. Assessing the Impact of Agricultural Research on Poverty Using the Sustainable Livelihoods Framework; FCND Discussion Paper 128, and EPTD Discussion Paper 89; International Food Policy Research Institute: Washington, DC, USA, 2002; p. 57.

34. Morse, S.; McNamara, N. Sustainable Livelihood Approach: A Critique of Theory and Practice; Springer Science \& Business Media: Dordrecht, The Netherlands, 2013.

35. Gillham, B. Research Interviewing: The Range of Techniques; McGraw Hill Education: Berkshire, UK, 2005.

36. Vallentine, J.F. Grazing Management; Academic Press Inc.: San Diego, CA, USA, 1990; pp. 302-308.

37. Campbell, B.; Sayer, J.A.; Frost, P.; Vermeulen, S.; Ruiz Perez, M.; Cunningham, A.; Prabhu, R. Assessing the performance of natural resource systems. Conserv. Ecol. 2001, 5, 22. [CrossRef]

38. Pouliotte, J.; Smit, B.; Westerhoff, L. Adaptation and development: Livelihoods and climate change in Subarnabad, Bangladesh. Clim. Dev. 2009, 1, 31-46. [CrossRef]

39. Uy, N.; Takeuchi, Y.; Shaw, R. Local adaptation for livelihood resilience in Albay, Philippines. Environ. Hazards 2011, 19, 139-153. [CrossRef]

40. McDowell, J.Z.; Hess, J. Accessing adaptation: Multiple stressors on livelihoods in the Bolivian Highlands under a changing climate. Glob. Environ. Chang. 2012, 22, 342-352. [CrossRef]

41. Wright, H.; Kristjanson, P.; Bhatta, G. Understanding Adaptive Capacity: Sustainable Livelihoods and Food Security in Coastal Bangladesh; CCAFS Working Paper No. 32; CGIAR Research Program on Climate Change, Agriculture and Food Security (CCAFS): Copenhagen, Denmark, 2012; p. 30.

42. Jacobs, B.; Nelson, R.; Kuruppu, N.; Leith, P. An Adaptive Capacity Guidebook: Assessing, Building and Evaluating the Capacity of Communities to Adapt in a Changing Climate; Southern Slopes Climate Change Adaptation Research Partnership (SCARP), University of Technology Sydney and University of Tasmania: Hobart, Tasmania, 2015; p. 20.

43. Quand, A. Measuring livelihood resilience: The Household Livelihood Resilience Approach (HLRA). World Dev. 2018, 107, 253-263. [CrossRef]

44. Vides, E. Interacción Entre Herbáceas y Gliricidia Sepium Bajo Diferentes Tipos de Fertilización y Prácticas de Manejo. Master's Thesis, El Colegio de La Frontera Sur, Chiapas, Mexico, 2011. (In Spanish)

45. SLE. Results of Soil Analysis. Soil Laboratory of El Colegio de La Frontera Sur (SLE); SLE: San Cristóbal de Las Casas, Mexico, 2019. 
46. Davis, B.; Winters, P.; Carletto, G.; Covarrubias, K.; Quiñones, E.J.; Zezza, A.; Stamoulis, K.; Azzarri, C.; DiGiuseppe, S. A cross-country comparison of rural income generating activities. World Dev. 2010, 38, 48-63. [CrossRef]

47. Abdul-Razak, M.; Kruse, S. The adaptive capacity of smallholder farmers to climate change in the Northern Region of Ghana. Clim. Risk Manag. 2017, 17, 104-122.

48. Defiesta, G.D.; Rapera, C.L. Measuring adaptive capacity of farmers to climate change and variability: Application of a composite index to an agricultural community in the Philippines. J. Environ. Sci. Manag. 2014, 17, 48-62.

49. Berkes, F.; Ross, H. Community resilience: Toward an integrated approach. Soc. Nat. Resour. $2013,26$. [CrossRef]

50. Wall, E.; Marzall, K. Adaptive capacity for climate change in Canadian rural communities. Local Environ. 2006, 11, 373-397. [CrossRef]

51. Reid, P.; Vogel, C. Living and responding to multiple stressors in South Africa-glimpses from KwaZulu-Natal. Glob. Environ. Chang. 2006, 16, 195-206. [CrossRef]

52. García-Barrios, L.; Galván-Miyoshi, Y.M.; Valdivieso-Pérez, I.A.; Masera, O.R.; Bocco, G.; Vandermeer, J. Neotropical forest conservation, agricultural intensification, and rural out-migration: The Mexican experience. BioScience 2009, 59, 863-873. [CrossRef]

53. Speelman, E.; Groota, J.C.J.; Garcia-Barrios, L.; Kokc, K.; van Keulend, H.; Tittonella, P. From coping to adaptation to economic and institutional change. Trajectories of change in land-use management and social organization in a Biosphere Reserve community, Mexico. Land Use Policy 2014, 41, 31-44. [CrossRef]

54. Abreu, M.; Grinevich, V.; Kitson, M.; Savona, M. Policies to enhance the 'hidden innovation' in services: Evidence and lessons from the UK, Service. Ind. J. 2008, 1, 99-118. [CrossRef]

55. IPCC. Climate change 2013: The physical science basis. In Contribution of Working Group I to the Fifth Assessment Report of the Intergovernmental Panel on Climate Change; Stocker, T.F., Qin, D., Plattner, G.K., Tignor, M., Allen, S.K., Boschung, J., Nauels, A., Xia, Y., Bex, V., Midgley, P.M., Eds.; Cambridge University Press: Cambridge, UK; New York, NY, USA, 2013; p. 1535.

56. Jarvis, A.; Lane, A.; Hijmans, J. The effect of climate change on crop wild relatives. Agric. Ecosyst. Environ. 2008, 126, 13-23. [CrossRef]

57. Murgueitio, R.E.; Ibrahim, M. Ganadería y medio ambiente en América Latina. In Ganadería del Futuro; Murgueitio, E., Cuartas-Cardona, C.A., Naranjo-Ramírez, J.F., Eds.; Fundacion CIPAV: Cali, Colombia, 2008; pp. 19-39. (In Spanish)

58. Alonso, J. Los sistemas silvopastoriles y su contribución al medio ambiente. Rev. Cuba. Cien. Agric. 2011, 45, 107-115.

59. Ibrahim, M.; Mora, J. Potencialidades de los sistemas silvopastoriles para la generación de servicios ambientales. In Potencialidades de los Sistemas Silvopastoriles para la Generación de Servicios Ambientales; Ibrahim, M., Mora, J., Rosales, M., Eds.; Centro Agronómico Tropical de Investigación y Enseñanza: Turrialba, Costa Rica, 2006; pp. 10-22. (In Spanish)

60. Murgueitio, R.E.; Chará, O.; Barahona, J.; Rolando, R.; Cuartas, C.C.; Naranjo, R.J. Los Sistemas Silvopastoriles intensivos (SSPi), herramienta de mitigación y adaptación al cambio climático. Trop. Subtrop. Agroecosyt. 2014, 17, 501-507.

61. Pagiola, S.; Ríos, A.; Arcenas, A. Can the poor participate in payments for environmental services? Lessons from the Silvopastoral project in Nicaragua. Environ. Dev. Econ. 2008, 13, 299-325. [CrossRef]

62. Bodin, Ö.; Crona, B.I. The role of social networks in natural resource governance: What relational patterns make a difference? Glob. Environ. Chang. 2009, 19, 366-374. [CrossRef]

63. Dedieu, B. Adaptación de los sistemas ganaderos e incertidumbres en el futuro. In Adaptación y Transformaciones de las Agriculturas Pampeanas a Inicios del Siglo XXI, 1st ed.; Gasselin, P., Cloquell, S., Mosciaro, M., Eds.; Fundación CICCUS: Ciudad Autónoma de Buenos Aires, Argentina, 2013; Volume 1, pp. 263-280. (In Spanish)

64. Delgadillo-Puga, C.; Sánchez-Muñoz, B.; Nahed-Toral, J.; Cuchillo-Hilario, M.; Díaz-Martínez, M.; Solis-Zabaleta, R.; Reyes-Hernández, A.; Castillo-Domíguez, R.M. Fatty acid content, health and risk indices, physicochemical composition, and somatic cell counts of milk from organic and conventional farming systems in tropical south-eastern Mexico. Trop. Anim. Health Prod. 2014, 46, 883-888. [CrossRef] [PubMed] 
65. Ulbricht, T.L.V.; Southgate, D.A.T. Coronary heart disease: Seven dietary factors. Lancet 1991, 338, $985-992$. [CrossRef]

66. Fox, J.; Haight, L. La política agrícola mexicana: Metas múltiples e intereses en conflicto. In Subsidios para la Desigualdad, las Políticas Públicas en México a Partir del Libre Comercio, 1st ed.; Fox, J., Haight, L., Eds.; Woodrow Wilson International Center for Scholars: Mexico city, Mexico, 2010; Volume 1, pp. 9-53. (In Spanish) 